\title{
Propagation et réflexion d'ondes de translation abruptes en eau tranquille de profondeur régulièrement décroissante
}

\author{
PAR G.-D. RANSFORD \\ B.A. (HONS), B.C.E., INGÉNIEUR-DOCTEUR, \\ INGENTEUR A LA SOGREAH
}

(English text, p. 410)

\begin{abstract}
Le problème de la propagation d'ondes de translation dans un remous s'est posé d̀ propos de deux importants aménagements hydroélectriques francais. Il s'est avéré important, en effet, de connaitre la variation de pente d'ondes de translation se propageant en ean tranquille de profondeur décroissante ainsi que l'augmentation de leur amplitade pendant la propagation et
\end{abstract}

\begin{abstract}
après réflexion. Il est possible de résondre theroriqument le premier probleme et la solution en est indiquée dans le présent article; par contre il n'existe pas de solution exacte pour le probleme de l'amplitude, mais certains résultats expérimentaux sont analysés d'après une théorie approchee.
\end{abstract}

\section{INTRODUCTION}

Le Laboratoire d'Hydraulique de la Sogrear, à Grenoble, a eu par deux fois l'occasion de traiter ce problème qui s'est posé à propos de l'étude de deux importants aménagements hydroélectriques francais.

Il s'est agi des conditions de navigation à cerlains endroits atteints par les ondes de débit résultant des variations brusques du régime de fonctionnement de ces centrales. Ce sont donc ces considérations purement pratiques qui ont conduit à entreprendre la présente étude. Du point de vue théorique, la première partie de notre étude, qui concerne la variation de pente de la pointe d'une onde de translation se propageant en eau tranquille de profondeur décroissante, et qui est basée sur la théorie des caractéristiques, ne constitue qu'un petit complément à l'ouvrage monumental de J. Massau (Mémoire sur l'intégration des équations aux dérivées partielles, Université de Gand). Les résultats obtenus sont exacts dans la mesure où sont exactes les équations que l'on utilise habitucllement pour l'écoulement non permanent en canaux, mais le fait de négliger les composantes verticales de la vitesse ou de l'accélération conduit à des résultats nécessairement inexacts dans une phase avancée de l'évolution des ondes.
Dans la deuxième partie de notre étude, qui concerne les amplitudes des fronts des ondes transmises et réfléchies, la théorie n'est pas d'un grand secours, et c'est pourquoi on devra compter davanlage sur l'analyse des résultats expérimentaux, qui sont eux-mêmes fragmentaires. Néanmoins, il semble que les conclusions auxquelles on aboutit sont suffisantes pour la pratique où, dans la majorité des cas, on n'a besoin, à vrai dire, que d'un résultat approximatit.

Les études théoriques et expérimentales se rapportent à des canaux de section rectangrulaire à pente constante.

\section{NOTATIONS}

$a=$ amplitude d'une petile onde de translation abrupte;

ò $a=$ augmentation de $a$ lorsque l'onde franchit in « décrochement»;

$b=$ coefficient de frottement, fonction de $s$ et $z$; $h=$ profondeur movenne de l'écoulement; c'est en général le rapport de la section mouillée à la largeur en surface. Dans un canal rectangulaire, pour lequel $i$ est constant :

$$
h=s i+z
$$


$i=$ pente du fond, que l'on supposera constant; $i$ est positif dans la figure 1;

$l=$ abscisse d'un point de référence;

$s=$ abscisse : c'est la distance mesurée le long de la surface de l'eau à partir du point de profondeur zéro (voir la fig. 1);

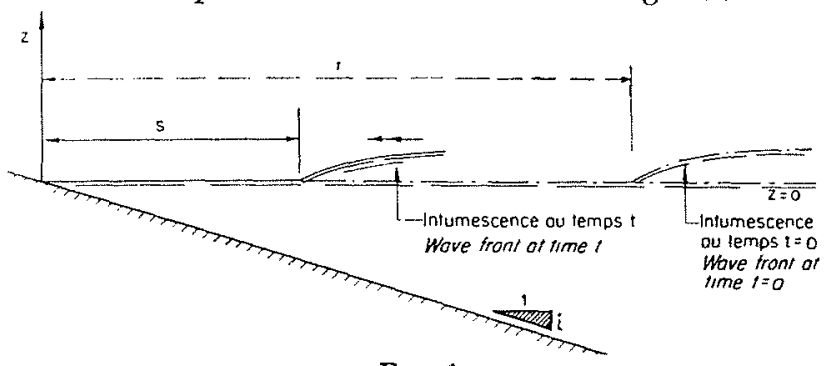

FIG. 1 $t=$ temps

$u=$ vitesse moyenne de l'écoulement $(u=0$ avant le passage de l'onde);

$z=$ cote de la surface de l'eau au-dessus du niveau initial de l'eau tranquille;

$k=$ constante d'intégration;

$\alpha=$ coefficient numérique tenant compte de la répartition non uniforme des vitesses dans les canaux. D'après Boulanger, cité par M. Massé (« Thèse sur l'amortissement des intumescences qui se produisent dans les eaux courantes $»$, Herman et Cie, Paris, 1935): $\alpha=1,095$;

$\beta=$ coefficient analogue; d'après le même auteur : $\beta=1,040$

$\Omega=$ vitesse de l'onde.

\section{PREMIERE PARTIE}

\section{VARIATION DE PENTE DE LA POINTE D'UNE ONDE DE TRANSLATION EN EAU TRANQUILLE DE PROFONDEUR DÉCROISSANTE (SOLUTION GÉNERALE)}

La méthode que nous utiliserons est celle instituée par Massau (le lecteur pourra d'ailleurs se référer à son ouvrage) et pour ne pas allonger par trop le texte, nous nous bornerons à en indiquer la ligne générale.

L'équation fondamentale de l'écoulement non permanent dans un canal de pente faible peut s'écrire :

$$
\frac{\partial z}{\partial s}+\frac{\alpha u}{g} \frac{\partial u}{\partial s}+\frac{\beta}{g} \frac{\partial u}{\partial t}=-b u^{2}
$$

L'équation de continuité prend la forme :

$$
\frac{\partial z}{\partial t}+u \frac{\partial z}{\partial s}+h \frac{\partial u}{\partial s}=-i u
$$

D'autre part, on a par définition :

$$
\begin{aligned}
d t \frac{\partial z}{\partial t}+d s \frac{\partial z}{\partial s} & =d z \ldots \\
d s \frac{\partial u}{\partial s}+d t \frac{\partial u}{\partial t} & =d u \ldots
\end{aligned}
$$

Nous nous occuperons d'abord de la propagation d'ondes de translation pour lesquelles $z$ et $u$ présentent des discontinuités infinitésimales et ont des dérivées indéterminées; nous exclurons de notre discussion les ondes d'amplitude finie.

On obtient la condition d'indétermination des dérivées en égalant à zéro les déterminants de la matrice formée par les coefficients des équations (1) à (4):

$\left\{\begin{array}{ccccc}0 & 1 & \frac{\alpha u}{g} & \frac{\beta}{g} & -b u^{2} \\ 1 & u & h & 0 & -i u \\ d t & d s & 0 & 0 & d z \\ 0 & 0 & d s & d t & d u\end{array}\right\}$

En considérant les quatre premières colonnes, on trouve l'ćquation de la vitesse d'onde :

$$
\frac{d s}{d t}=\left(\frac{\alpha+\beta}{2 \beta}\right) u \pm \sqrt{\frac{g h}{\beta}+u^{2}\left(\frac{\theta-\beta}{2 \beta}\right)^{2}} \ldots
$$

Pour la pointe d'une onde se propageant en eall tranquille, on a :

$$
\frac{d s}{d t}= \pm \sqrt{\frac{g h}{\beta}}
$$

L'autre "équation caractéristique » pour les ondes se propageant en eau tranquille est obtenue en considérant les deux premières et les deux dernières colonnes, avec $\boldsymbol{u}=0$ :

$$
d z=\sqrt{\frac{\beta h}{g}} d u=0
$$

Cherchons maintenant la variation de pente du « dièdre » constituant la pointe d'une onde de translation. Dans ce cas, il y a des discontinuités dans les dérivées premières, et les dérivées secondes sont indéterminées. En prenant les dérivées partielles de (1) et (2) par rapport à $s$, on lrouve que la matrice dont les déterminants doivent être nuls est :

$$
\begin{aligned}
& 01 \frac{\alpha u}{g} \frac{\beta}{g}-\left\{\frac{\alpha}{g}\left(\frac{\partial u}{\partial s}\right)^{2}+2 b u \frac{\partial u}{\partial s}+u^{2} \frac{\partial b}{\partial s}+u^{2} \frac{\partial b}{\partial z} \frac{\partial z}{\partial s}\right\} \\
& \left.\begin{array}{llll}
1 & u & h & 0
\end{array}-\left\{i \frac{\partial u}{\partial s}+\frac{\partial u}{\partial s} \frac{\partial z}{\partial s}+\frac{\partial h}{\partial s} \frac{\partial u}{\partial s}+\frac{\partial h}{\partial z} \frac{\partial z}{\partial s} \frac{\partial n}{\partial s}\right\}\right) \\
& \int \begin{array}{lllll}
d t & d s & 0 & 0 & d\left(\frac{\partial z}{\partial s}\right)
\end{array} \\
& \begin{array}{llll}
0 & 0 & d s & d t
\end{array} \quad d\left(\frac{\partial u}{\partial s}\right)
\end{aligned}
$$


Pour la pointe d'une onde de translation se propageant en eau tranquille, le dernier terme de la première ligne se réduit à :

$$
-\frac{\alpha}{g}\left(\frac{\partial u}{\partial s}\right)
$$

et le dernier terme de la deuxième ligne devient :

$$
-2\left[i \frac{\partial u}{\partial s}+\frac{\partial z}{\partial s} \cdot \frac{\partial u}{\partial s}\right]
$$

Dans le cas d'un canal rectangulaire :

et :

$$
\left(\frac{\partial h}{\partial s}\right)_{z}=i
$$

$$
\left(\frac{\partial h}{\partial z}\right)_{s}=1
$$

Alors que la première «équation caractéristique » fournit comme auparavant l'équation (7) pour la vitesse de la pente de l'onde, la deuxième équation caractéristique [qui correspond à (8)] peut s'écrire :

$d\left(\frac{\partial z}{\partial s}\right) \pm \sqrt{\frac{\beta h}{g}} d\left(\frac{\partial u}{\partial s}\right)$

$=-\frac{\alpha}{g}\left(\frac{\partial u}{\partial s}\right)^{2} d s-2\left\{i \frac{\partial u}{\partial s}+\frac{\partial z}{\partial s} \frac{\partial u}{\partial s}\right\} d t$

En utilisant l'équation (2) en eau tranquille, on trouve à la pointe de l'onde :

$$
\frac{\partial u}{\partial s}=-\frac{1}{h} \frac{\partial z}{\partial t}
$$

Par conséquent :

$$
\frac{\partial u}{\partial s}= \pm \sqrt{\frac{g}{h \beta}} \frac{\partial z}{\partial s}
$$

puisque, au front de l'onde :

$\frac{d z}{d t}=\frac{\partial z}{\partial t}+\frac{\partial z}{\partial s} \frac{d s}{d t}=\frac{\partial z}{\partial t} \pm \sqrt{\frac{g h}{\beta}} \frac{\partial z}{\partial s}=0$

De l'équation (12), il résulte que :

$2 d\left(\frac{\partial z}{\partial s}\right)-\frac{1}{2 h} \frac{\partial z}{\partial s} d h$

$=-\frac{\alpha}{\beta h}\left(\frac{\partial z}{\partial s}\right)^{2} d s-\frac{2}{h}\left\{i \frac{\partial z}{\partial s}+\left(\frac{\partial z}{\partial s}\right)^{2}\right\} d s$

Or, par définition, $d h / d s=i$.

L'équation (14), exprimée en fonction des dérivées totales par rapport à $s$, devient donc :

$2 \frac{d}{d s}\left(\frac{\partial z}{\partial s}\right)=-\frac{1}{h}\left\{2+\frac{\alpha}{\beta}\right\}\left(\frac{\partial z}{\partial s}\right)^{2}-\frac{3 i}{2 h}\left(\frac{\partial z}{\partial s}\right)$
Pour simplifier les formules, on peut admettre, sans commettre d'erreur appréciable, que :

$$
\frac{\alpha}{\beta}=1
$$

L'équation (15) devient alors :

$$
\frac{d}{d s}\left(\frac{\partial z}{\partial s}\right)=-\frac{3}{2 h}\left(\frac{\partial z}{\partial s}\right)^{2}-\frac{3 i}{4 h}\left(\frac{\partial z}{\partial s}\right) \ldots
$$

Il est aisé d'intégrer cette équation fondamentale qui fournit la variation de pente de la pointe de l'onde lorsque cette dernière progresse. On trouve que :

$$
\left(\frac{\partial z}{\partial s}\right)_{s}=\frac{i / 2}{k s^{3 / 4}-1}
$$

compte tenu de ce que $h=s i$ à la pointe de l'onde.

Si l'on calcule $k$ en fonction de $(\partial z / \partial s)_{r}$, pente à la pointe de l'onde au point initial $r$ (supposée connue), l'équation (17) prend la forme suivante qui est l'équation générale cherchée :

$$
\left(\frac{\partial z}{\partial s}\right)_{s}=\frac{(\partial z / \partial s)_{r}}{\left(\frac{s}{r}\right)^{3 / 4}+\frac{2}{i}\left[\left(\frac{s}{r}\right)^{3 / 4}-1\right]\left(\frac{\partial z}{\partial s}\right)_{r}}
$$

Dans le cas particulier d'un canal à fond horizontal, la solution de l'équation (16) est :

$$
\left(\frac{\partial z}{\partial s}\right)_{s}=\frac{2 h}{3 s+k}
$$

ou bien, en choisissant convenablement l'origine de $s$ :

$$
\left(\frac{\partial z}{\partial s}\right)_{s}=\frac{2 h}{3 s}
$$

A propos de l'équation (18) on peut faire les remarques suivantes :

1. La pointe d'une onde de translation positive, de pente initiale finie, se propageant dans un canal en eau tranquille de profondeur décroissante, finit toujours par déferler. En effet, d'après les conventions de signe de la figure $1,(\partial z / \partial s)$. est positif mais le terme $\left[(s / r)^{3 / 4}-1\right]$ est négatif; le dénominateur est nul pour :

$$
s=r\left[\frac{\{\partial z / \partial s\}_{r}}{i / 2+\{\partial z / \partial s\}_{r}}\right\rceil^{t / 3} \ldots
$$

2. Pour les ondes de translation négalives, l'équation (18) fournit la pente théorique en tout point. En particulier :

$$
\operatorname{Lit}_{s \rightarrow 0}\left(\frac{\partial z}{\partial s}\right)=-\frac{i}{2}
$$


Il résulte du caractère monotone de la foncLion représentée par l'équation (18) que :

a) Les ondes de translation négatives pour lesquelles $\left|(\partial z / \partial s)_{r}\right|<i / 2$ se raidissent lorsqu'elles s'approchent de l'origine (voir fig. 2).

b) Les ondes de translation négatives pour lesquelles $\left|(\partial z / \partial s)_{r}\right|=i / 2$ conservent cette pente à la pointe.

c) Les ondes de translation négatives pour lesquelles $\left|(\partial z / \partial s)_{r}\right|>i / 2$ s'aplatissent à la pointe.

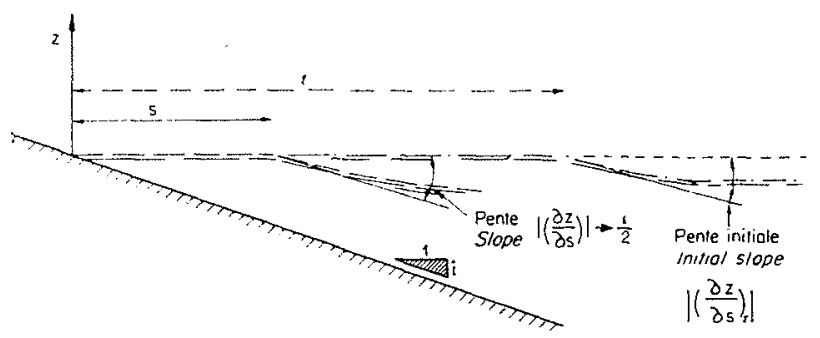

FrG. 2

En eau tranquille de profondeur corsoiante, une onde de translation positive de pente initiale finie finira toujours, d'après la théorie, par déferler alors que le front d'une onde négative s'aplatira indéfiniment : c'est ce que l'on peut déduire de l'équation (20).

La seule condition nécessaire pour que ces conclusions soient valables est que la pente de la pointe de l'onde soit finie au point de départ. Cela signifie, si l'on s'exprime en fonction du débit, que l'onde initiale doit être provoquée par une variation finie de débit, disons $(d \mathrm{Q} / d t)$, en un point quelconque de l'ensemble canal-remous.
La discontinuité doit se trouver dans la dérivée première; par une méthode semblable à celle que nous avons exposée, on pourrait évidemment étudier aussi une discontinuité se présentant seulement dans les dérivées seconde ou d'ordre supérieur, comme ce serait le cas pour une loi de débit du type :

$$
\begin{aligned}
& \mathrm{Q}=\mathrm{Q}_{0} \text { pour } t<t_{0} \\
& \mathrm{Q}=\mathrm{Q}_{0}+a t^{2} \text { pour } t \geqslant t_{0}
\end{aligned}
$$

Il convient également de faire mention de certaines remarques formulées à cet égard par M. le Directeur des Etudes à la Compagnie Nationale du Rhône, M. Henry, qui a fait exécuter des mesures sur le raidissement des ondes à l'aval du barrage de Génissiat lors d'un lâcher subit de débit sur ce tronçon du fleuve : il a pu constater que la théorie n'élait pas suivie pour des variations initiales faibles du régime d'écoulement, le raidissement prévu n'existant pas. Il est possible, bien entendu, que cette anomalie soit due, en partie tout au moins, à la diffraction initiale de l'onde, le lâcher s'étant produit sur la rive gauche du fleuve un peu en aval des ouvrages, au débouché de la galerie de dérivation provisoire.

Dernière remarque : lors d'un brusque changement de pente du fond, comme e'est le cas par exemple quand une onde de translation formée dans une eau de profondeur constante pénètre dans un canal incliné, il y aura une variation brusque de la pente de la pointe de l'onde, tout comme il se produit une variation d'amplitude au droit d'un décrochement du fond du canal, ainsi que nous le verrons plus loin. Ce problème a été étudié par le savant hollandais, Dr. J. C. SGHÖNFELD.

\section{DEUXIEME PARTIE}

\section{VARIATION D'AMPLITUDE DE LA PARTIE FRONTALE D'UNE ONDE DE TRANSLATION SE PROPAGEANT EN EAU TRANQUILLE DE PROFONDEUR DÉCROISSANTE}

Le seul résultat théorique que l'on puisse utiliser pour cette étude concerne la variation d'amplitude d'une onde abrupte d'amplitude « infinitésimale $\gg$ se propageant dans une eau de profondeur variable; A. Craya l'a donné, par exemple, dans son article: "Calcul des régimes variables dans les canaux », la Houille Blanche, $\mathrm{N}^{\circ} 1$ et 2,1945 .

On peut obtenir très simplement le même résultat en opérant de la manière ci-après exposée. Nous allons chercher l'augmentation d'amplitude d'une onde de translation abrupte de hauteur $a$ lorsqu'elle franchit le décrochement d'un canal dont l'eau est initialement tranquille (fig. 3).

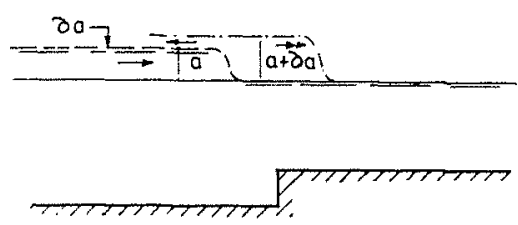

FIG. 3 
Soit - ¿s h la diminution de profondeur ou hauteur du décrochement dans le cas considéré. Prenons pour la vitesse de l'onde la formule de H. Favre par exemple (consulter «Etude théorique et expérimentale des ondes de translation dans les canaux découverts », Dunod, Paris, 1935). Pour un canal rectangulaire de largeur constante, on a :

$$
\Omega=\sqrt{g h} ! 1+\frac{3 a}{4 h} \vdots \quad \ldots
$$

Le front de l'onde est accompagné d'un débit $q$ par unité de largeur égal à :

$$
a \Omega=a \sqrt{g h} ! 1+\frac{3 a}{4 h} \vdots
$$

Ecrivons maintenant l'équation de continuité lorsque l'onde passe au droit du décrochement où elle donne naissance à une onde réfléchie d'amplitude $\delta a$ et à une onde transmise d'amplitude $(a+\delta a)$ :

$$
\begin{aligned}
& a \sqrt{g h}\left\{1+\frac{3 a}{4 h}\right\} \\
& =(a+\delta a) \sqrt{g(h-\delta h)}\left\{1+\frac{3(a+\delta a)}{4(h-\delta h)}\right\} \\
& +\delta \alpha\left[\sqrt{g(h+a)} ! 1+\frac{3 \delta a}{4(h+a)} \vdots-\frac{q}{h+a}\right]
\end{aligned}
$$

Si l'on admet que $a$ est une quantité petite du premier ordre et $\delta a$ une quantité du deuxième ordre, on tire :

$$
\frac{\delta \alpha}{a}+\frac{\delta h}{4 h}=0
$$

En intégrant, on trouve donc que dans un canal à fond incliné :

$$
a^{4} h=\text { Const. }
$$

Cette relation n'est valable que pour les petites valeurs de $a / h$ et dans la pratique elle ne présente pas un grand intérêt; on constate néanmoins que la propagation d'une onde de translation du genre mascaret, dans un chenal incliné, peut être caractérisée par une nette augmentation d'amplitude de l'onde transmise et de l'onde réfléchie.

D'autre part, on peut étudier la réflexion d'une onde de translation dans le cas limite d'une paroi verticale barrant un canal de profondeur constante en utilisant l'équation (25): le premier terme du deuxième membre disparait et les quantités $a$ et $\delta a$ sont toutes deux du premier ordre. On trouve :

$$
\delta a=a\left(1+\frac{a}{2 h}\right)
$$

de sorte que l'élévation totale du niveau après le retour de l'onde réfléchie est donnée par :

$$
a+\delta a=2 a+\frac{a^{2}}{2 h}
$$

\section{TROISIĖME PARTIE. - ÉTUDE EXPÉRIMENTALE}

Les expériences ont été effectuées dans le canal représenté sur la figure 4. Le mode opératoire était le suivant : on établissait d'abord le

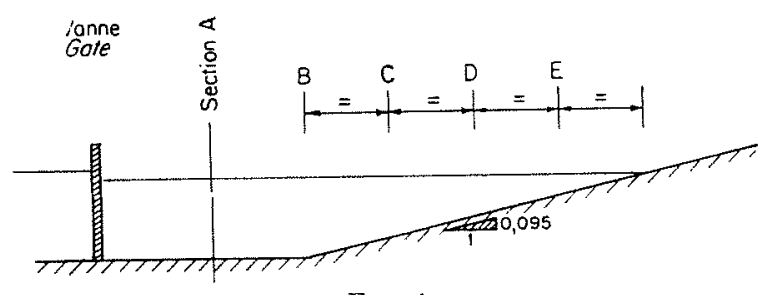

FIG. 4

niveau du bassin à niveau constant par remplissage au seau (ou siphonage); puis on levait rapidement la vanne située à une extrémité du canal et le mouvement ainsi provoqué était enregistré à cinq points par des enregistreurs électroniques d'onde du type inventé par M. Boudan et que ce dernier a décrit dans * Appareils pour la me- sure des niveaux rapidement variables sur modèle réduit $\gg$. La Houille Blanche, $\mathrm{n}^{\circ} 4$, aoûtseptembre 1953.

Dans une première série d'essais, les parois et le fond du canal étaient lisses (coefficient de Chézy égal à 60 et 70 dans le système métrique pour un rayon hydraulique respectivement égal à $0,02 \mathrm{~m}$ et $0,10 \mathrm{~m}$ ), alor's que dans la deuxième série d'essais il y avait une rugosité supplémentaire. Du point de vue de la théorie classique des ondes de translation, ce deuxième cas équivaut à diminuer la pente du fond sans modifier la rugosité, la transmission et la réflexion des ondes s'effectuant exactement comme si, tout en conservant le même état des parois, la pente était d'environ dix fois plus faible que dans le premier cas, c'est-à-dire comme si elle était d'environ $0,95 \%$ au lieu de $9,5 \%$.

Il s'est avéré difficile de suivre la variation de hauteur de l'onde initiale. Cependant, pour une onde de $20 \mathrm{~mm}$ se propageant dans une eau dont 
la profondeur initiale dans la section A est d'environ $300 \mathrm{~mm}$ (pour les ondes positives) ou $340 \mathrm{~m}$ (pour les ondes négatives), la montée ou l'abaissement maximum du niveau de l'eau ne dépasse pas $2 a$ (soit $40 \mathrm{~mm}$ ) de plus de $10 \%$ sur les $85 \%$ (ondes positives) ou $60 \%$ (ondes négatives) du parcours compté sur la longueur initiale de la surface libre au-dessus du fond incliné, soit $85 \%$ de $3,15 \mathrm{~m}$ et $60 \%$ de $3,60 \mathrm{~m}$. Ces chiffres se rapportent au canal lisse; avec une rugosité artificielle, la différence maximum de niveau était, grosso modo, inférieure de $10 \%$, de sorte qu'en fait la différence de niveau n'atteignait jamais $40 \mathrm{~mm}$ sur les distances précitées. I1 n'était pas possible de mesurer directement la différence maximum de niveau à l'extrémité du canal où le front de l'onde déferle (même localement pour les ondes négatives, pendant la rćflexion) ni de maintenir en permanence la tige électrique sous l'eau; néanmoins, on pouvait estimer cette différence maximum de niveau à environ $55 \mathrm{~mm}$ au-dessus du niveau initial (soit une augmentation de 35 à $40 \%$ au-dessus de
$2 a=40 \mathrm{~mm}$ ) pour les ondes positives et lá pente forte, et à environ $55 \mathrm{~mm}$ au-dessous du niveau initial pour les ondes négatives; avec la rugosité artificielle, on pouvait s'attendre à une augmentation de 25 à $30 \%$, de sorte qu'une fois encore le choix d'une pente dix fois moins forte, sans modifier la rugosité, équivaudrait à diminuer d'environ $10 \%$ le pourcentage devant être ajouté à deux fois l'amplitude initiale pour déterminer' la dénivellation extrême.

Les enregistrements n'ont pas permis d'étudier avec précision la variation de pente du front de l'onde.

Ces résultats montrent que la réflexion sur un fond lisse en pente peut être plus défavorable que sur une paroi vertica!e (équation 28) dans le cas de fortes pentes, mais aussi que la zone soumise à l'augmentation la plus notable est celle des tres faibles profondeurs. Pour des canaux à pente plus faible ( 1 \% ou moins), l'amplitude de l'onde ne pourra dépasser nettement le double de sa valeur, si tant est que cela arrive, que dans les profondeurs très faibles.

\section{CONCLUSIONS PRATIQUES}

La principale conclusion que l'on peul tirer est la suivante : les difficultés rencontrées par les pénicbes du fait de la propagation d'ondes de translation en eau peu profonde sont vraisemblablement liées au raidissement et au déferlement inévitables des ondes positives; voir la première partie de l'article.

Rarement, en pratique, la montée et l'abaissement du niveau de l'eau seront très différents des valeurs obtenues dans le cas de la réflexion sur une paroi verticale que nous avons étudiée dans la deuxicme partie; cette assertion est fondée sur les' résultats expérimentaux exposés dans la troisième partie.

Le lecteur qui désirerait rapprocher le sujet traité ici d'autres parties de la mécanique des fluides pourra utilement consulter l'article de J.J. Stoker sur la « Formation of breakers and bores » paru dans les Communications on Applied Mathematics, vol. $1, \mathrm{n}^{\circ} 1,1948$. 


\title{
The propagation and the reflection of abrupt translation waves in still water of steadily decreasing depth
}

\author{
BY G.-D. RANSFORD \\ 33.A. (HONS), B.C.E., INGÉNIEUR DOCTEUR, \\ INGÉNIEUR A LA SOGREAH \\ (Texte français, p. 404)
}

\begin{abstract}
The problem of the propagation of translation waves in a shelving backwater has arisen in connection with two large French power schemes. It has proved important to know both the change in slope of translation waves moving in still water of decreasing depth, and also the increase of amplitude occurring during
\end{abstract}

propagation and after reflection. The first problem can be treated theoretically, and the solution is given in this article; no exact solution exists for the amplitude problem, but certain experimental results will be analysed on an approximate theoretical basis.

\section{INTRODUCTION}

The problem treated in the present article has been studied by the staff of the Sogrear Hydraulic Laboratory at Grenoble for two large French hydroelectric projects where navigation problems arose.

The stimulus for the present investigation arose therefore from strictly practical considerations. From a theoretical standpoint, the first part of our study, which concerns the change in slope of the tip of a translation wave moving into still water of decreasing depth, forms a small addendum to the monumental work of J. Massau (Mémoire sur l'intégration des équations aux dérivées partielles, University of Ghent), being based on the theory of characteristics. The results obtained are exact to the extent that the usually accepted equations for non-permanent flow in open channels are exact, but the neglect of vertical components of velocity or of acceleration leads to necessarily inexact results at an advanced stage of the motion.

In the second part of the study, concerning the amplitudes of the "oncoming" and " reflected" wave fronts along the canal, theory is of little aid; reliance will therefore be placed on an analysis of the experimental results, which themselves are fragmentary. Nevertheless, it is felt that the conclusions reached are sufficient for practical purposes, where an approximate result is all that is really required in the majority of cases.
Both the theoretical and experimental studies concern canals of rectangular cross-section and of constant slope.

\section{SYMBOLS}

$a=$ amplitude of a small, abrupt translation waves;

$\delta a=$ increase in $a$ as wave moves over a " step";

$b=$ friction factor, function of $s$ and $z$;

$h=$ mean depth of flow; in general, the ratio of the wetted cross-section to the surface width. In a rectangular channel, with constant $i$,

$$
h=s i+z
$$

$i=$ bottom slope, here supposed constant; positive in figure 1 (French text);

$r=$ abscissa of a reference point;

$s=$ abscissa; distance measured along the water surface from the point of zero

$t=$ time; depth (see fig. 1);

$u=$ mean velocity of flow $(u=0$ prior to the passage of the wave);

$z=$ altitude of water surface above original still water level;

$k=$ constant of integration; 
$\alpha=a$ numerical factor taking account of the non-uniform velocity distribution in open channel flow. According to Bovlanger, cited by Mr. MassÉ, $\alpha=1,096$; $\beta=$ a similar factor $\beta=1.040$ according to the same authorities;

$\Omega=$ wave velocity.

\section{A GENERAL SOLUTION FOR THE CHANGE IN SLOPE OF THE TIP OF A TRANSLATION WAVE MOVING INTO STILL WATER OF DECREASING DEPTH}

The method to be used is that given by Massau, and the interested reader should consult his work; in order to avoid undue length in the text, only the barest outline will be given here.

The basic equation of non-permanent flow in a canal of small slope may be written :

$$
\frac{\partial z}{\partial s}+\frac{\alpha u}{g} \frac{\partial u}{\partial s}+\frac{\beta}{g} \frac{\partial u}{\partial t}=-b u u^{2}
$$

The continuily equation takes the form:

$$
\frac{\partial z}{\partial t}+u \frac{\partial z}{\partial s}+h \frac{\partial u}{\partial s}=--i u
$$

On the other hand, it follows by definition that:

$$
\begin{aligned}
d t \frac{\partial z}{\partial t}+d s \frac{\partial z}{\partial s} & =d z \ldots \\
d s \frac{\partial u}{\partial s}+d t \frac{\partial u}{\partial t} & =d u \ldots
\end{aligned}
$$

(i) Our interest lies in the propagation of translation waves giving rise in the first instance to infinitesimal discontinuities in $z$ and $l l$, and to indeterminacy in their derivatives; finite amplitude waves will be excluded from the present discussion.

The condition of indeterminacy of the derivatives is obtained by equating to zero the determinants of the matrice formed by the coefficients of equations (1) to (4) :

$$
\left\{\begin{array}{ccccc}
0 & 1 & \frac{\alpha u}{g} & \frac{\beta}{g} & -b u^{2} \\
1 & u & h & 0 & -i u \\
d t & d s & 0 & 0 & d z \\
0 & 0 & d s & d t & d u
\end{array}\right\} \ldots
$$

Taking the first four columns, we find the wave velocity equation :

$$
\frac{d s}{d t}=\left(\frac{\alpha+\beta}{2 \beta}\right) u \pm \sqrt{\frac{g h}{\beta}+u^{2}\left(\frac{\alpha-\beta}{2 \beta}\right)^{2}} \cdots
$$

For the tip of a wave moving into still water, we find :

$$
\frac{d s}{d t}= \pm \sqrt{\frac{\overline{g h}}{\beta}}
$$

The other " characteristic equation" for waves moving into still water, is obtained from the first two and the last two colums, with $u=0$ :

$$
d z=\sqrt{\frac{\beta h}{g}} d u=0
$$

(ii) We shall now focus our attention on the change in slope of the tip of a translation wave. In this case, there are discontinuities in the first derivatives, and the indeterminacy affects the second derivatives. Taking the partial derivalives with respect to $s$ of (1) and (2), we find that the matrice of which the determinants should be zero is :

$0 \quad 1 \frac{\alpha u}{g} \frac{\beta}{g}-\left\{\frac{\alpha}{g}\left(\frac{\partial u}{\partial s}\right)^{2}+2 b u \frac{\partial u}{\partial s}+u^{2} \frac{\partial b}{\partial s}+u^{2} \frac{\partial b}{\partial z} \frac{\partial z}{\partial s}\right\rangle$

$\left.1 \quad u \quad h \quad 0-i \frac{\partial u}{\partial s}+\frac{\partial u}{\partial s} \frac{\partial z}{\partial s}+\frac{\partial h}{\partial s} \frac{\partial u}{\partial s}+\frac{\partial h}{\partial z} \frac{\partial z}{\partial s} \frac{\partial u}{\partial s}\right\}$

$\begin{array}{lllll}d t & d s & 0 & 0 & d\left(\frac{\partial z}{\partial s}\right)\end{array}$

$$
0 \quad d s d t \quad d\left(\frac{\partial u}{\partial s}\right)
$$

Considering now the case of the tip of a translation wave moving into still water, the upper right hand bracket reduces to:

$$
-\frac{\alpha}{g}\left(\frac{\partial n}{\partial s}\right)
$$

and the bracket below it to:

$$
-2\left\lceil i \frac{\partial u}{\partial s}+\frac{\partial z}{\partial s} \cdot \frac{\partial u}{\partial s}\right\rceil
$$


Taking the case of a rectangular channel :

$$
\left(\frac{\partial h}{\partial s}\right)_{z}=i
$$

and :

$$
\left(\frac{\partial h}{\partial z}\right)_{s}=1
$$

The first "characteristic equation" gives the wave-tip velocity formula (7), as before, while the second characteristic equation, corresponding to (8), may be written :

$$
\begin{aligned}
& d\left(\frac{\partial z}{\partial s}\right) \pm \sqrt{\frac{\beta h}{g}} d\left(\frac{\partial u}{\partial s}\right) \\
& =-\frac{\alpha}{g}\left(\frac{\partial u}{\partial s}\right)^{2} d s-2\left\{i \frac{\partial u}{\partial s}+\frac{\partial z}{\partial s} \frac{\partial u}{\partial s}\right\} d t
\end{aligned}
$$

Using (2) in still water, we find at the tip of the wave :

Hence :

$$
\frac{\partial u}{\partial s}=-\frac{1}{h} \frac{\partial z}{\partial t}
$$

$$
\frac{\partial u}{\partial s}= \pm \sqrt{\frac{g}{h \beta}} \frac{\partial z}{\partial s}
$$

since at the front of the wave :

$\frac{d z}{d t}=\frac{\partial z}{\partial t}+\frac{\partial z}{\partial s} \frac{d s}{d t}=\frac{\partial z}{\partial t} \pm \sqrt{\frac{g h}{\beta}} \frac{\partial z}{\partial s}=0$

From (12) it follows that :

$$
\begin{aligned}
& 2 d\left(\frac{\partial z}{\partial s}\right)-\frac{1}{2 h} \frac{\partial z}{\partial s} d h \\
& =-\frac{\alpha}{\beta h}\left(\frac{\partial z}{\partial s}\right)^{2} d s-\frac{2}{h}\left\{i \frac{\partial z}{\partial s}+\left(\frac{\partial z}{\partial s}\right)^{2}\right\} d s
\end{aligned}
$$

Now $\frac{d h}{d s}=i$, by definition.

In terms of total derivatives with respect to $s$, (14) becomes :

$2 \frac{d}{d s}\left(\frac{\partial z}{\partial s}\right)=-\frac{1}{h}\left\{2+\frac{\alpha}{\beta}\right\}\left(\frac{\partial z}{\partial s}\right)^{2}-\frac{3 i}{2 h}\left(\frac{\partial z}{\partial s}\right)$

Without appreciable error, we may, in order to simplify the formulae suppose that:

$$
\frac{\alpha}{\beta}=1
$$

Equation (15) becomes:

$$
\frac{d}{d s}\left(\frac{\partial z}{\partial s}\right)=-\frac{3}{2 h}\left(\frac{\partial z}{\partial s}\right)^{2}-\frac{3 i}{4 h}\left(\frac{\partial z}{\partial s}\right) \ldots
$$

This basic equation giving the change in slope of the wave tip as the wave advances may be readily integrated; we find that:

$$
\left(\frac{\partial z}{\partial s}\right)_{s}=\frac{i / 2}{k s^{3 / t}-1}
$$

remembering that $h=s i$ at the wave tip. Evaluating $k$ in terms of $(\partial z / \partial s)_{r}$, the wave tip slope (supposed known) at an initial point $r$, we find that (17) transforms into the following equation, which is the general solution sought:

$$
\left(\frac{\partial z}{\partial s}\right)_{s}=\frac{(\partial z / \partial s)_{r}}{\left(\frac{s}{r}\right)^{3 / 4}+\frac{2}{i}\left[\left(\frac{s}{r}\right)^{3 / 4}-1\right]\left(\frac{\partial z}{\partial s}\right)_{r}}
$$

In the special case of a horizonlal bottom, the solution of (16) is :

$$
\left(\frac{\partial z}{\partial s}\right)_{s}=\frac{2 h}{3 s+k}
$$

or, if the origin of $s$ is suitably chosen :

$$
\left(\frac{\partial z}{\partial s}\right)_{s}=\frac{2 h}{3 s}
$$

The following remarks can be made concerning (18) :

(i) A positive translation wave tip of finite initial slope moving into a still-water channel of decreasing depth will finally" always break. In effect, with the sign conventions of fig 1 , $(\partial z / \partial s)_{r}$ is positive but the factor $\left[(s / r)^{3 / 4}-1\right]$ is negative; for:

$$
s=r\left[\frac{\{\partial z / \partial s\}_{r}}{i / 2+\{\partial z / \partial s\}_{r}}\right]^{4 / 3} \ldots
$$

the denominator of (18) is zero.

(ii) For negative translation waves, (18) gives the theoretical slope at any point. In particular :

$$
\underset{s \rightarrow 0}{\boldsymbol{L}_{t}}\left(\frac{\partial z}{\partial s}\right)=-\frac{i}{2}
$$

It follows from the monotonic character of (18) that :

a) Negative translation waves for which $\left|(\partial z / \partial s)_{r}\right|<i / 2$ steepen up as they approach the origin (see fig. 2 in the french text);

b) Negative translation waves for which $\left|(\partial z / \partial s)_{r}\right|=i / 2$ retain this slope at the tip;

c) Negative translation waves for which $\mid \partial z / \partial s)_{r} \mid>i / 2$ flatten out at the tip.

In the case of still water of constant depth, a positive translation with finite initial slope will, according to the theory, always finish up by breaking whereas a negative wave tip will flatten out indefinitely. These conclusions are deduced from equation (20).

The only requirement for the validity of these 
conclusions concerns the finite slope of the wave tip at the point of departure. In terms of discharge, this means that the original wave must result from a finite rate of change of flow, $(d \mathrm{Q} / d t)$ say, at some point in the canal system connecting with the backwater. The discontinuity must be in the first derivative; a discontinuity in the second or higher derivatives only, such as would be occasioned by a law of discharge :

$$
\begin{aligned}
& \mathrm{Q}=\mathrm{Q}_{0} \text { for } t<t_{0} \\
& \mathrm{Q}=\mathrm{Q}_{0}+a t^{2} \text { for } t \geqslant t_{0}
\end{aligned}
$$

could of course also be studied by a method similar to that outlined here.

Mention should also be made of certain remarks of M. Henry, the Director of Designs of the Compagnie Nationale du Rhône. Tests on the steepening of a flood wave caused by the sudden increase of discharge through dam outlet structures showed that the theoretical predictions were not accurate; the expected steepening up did not occur. This anomaly may be partly explained at least by the initial diffraction of the flood wave, as the outlet was on the left bank of the Rhône some distance downstream from the dam.

Finally, it should be observed that, in the event of an abrupt change in bottom slope, as is for example the case when a translation wave formed in water of constant depth enters a shelving canal, an abrupt change in the slope of the wave tip will occur, analogously to the change in amplitude occurring over a "step" in the canal bottom, as investigated below. This problem has' been studied by Dr. J.C. Schönfrud in Holland.

\section{THE CHANGE IN AMPLITUDE OF THE FRONTAL PART OF A TRANSLATION WAVE MOVING INTO STILL WATER OF DECREASING DEPTH}

The only theoretical result which can be used in this study concerns the change in amplitude of an abrupt wave of "infinitesimal " amplitude travelling in water of variable depth, and has been given for example by A. CRAYA in his article « Calcul des régimes variables dans les canaux », la Houille Blanche, $\mathrm{N}^{\circ s} 1$ ef $2,1945$.

The same result can be obtained very simply in the following manner :

Referring to fig. 3, we shall study the increase in amplitude of an abrupt translation wave of height $a$ as it moves over a "step" in a canal initially containing still water.

Let - $\delta h$ be the decrease in depth, or height of the step in the case considered. Taking the formula for wave velocity as given by H. FAvRe, for example (see the book « Etude théorique et expérimentale des ondes de translation dans les canaux découverts », Dunod, Paris, 1935); we have :

$$
\Omega=\sqrt{g h}\left\{1+\frac{3 a}{4 h}\right\} \quad \ldots
$$

in a constant-width, rectangular canal. The wave front is accompanied by a discharge $q$ per unit width equal to :

$$
a \Omega=a \sqrt{g h}\left\{1+\frac{3 a}{4 h}\right\}
$$

Writing now the equation of continuity for the wave as it passes over the step, where it gives rise to a reflected wave of amplitude $\delta \alpha$ and a transmitted wave of amplitude $(a+\delta a)$ we have:

$$
\begin{aligned}
& \left.a \sqrt{g h} !+\frac{3 a}{4 h}\right\} \\
& \left.=(a+\delta a) \sqrt{g(h-\delta h)} i 1+\frac{3(a+\delta a)}{4(h-\delta h)}\right\} \\
& \left.+\delta a\left[\sqrt{g(h+a)} ! 1+\frac{3 \delta a}{4(h+a)}\right\}-\frac{q}{h+a}\right]
\end{aligned}
$$

If it be supposed that $a$ is a first-order small quantity, and $\delta \alpha$ a second order one, it follows that :

$$
\frac{\delta a}{a}+\frac{\delta h}{4 h}=0
$$

By integration, it is thus found that, in the case of a canal with a sloping bottom :

$$
a^{4} h=\text { Const. }
$$

This relationship holds only for small values of $a / h$ and in practice, is wihout great value; however, it is seen that one feature of the propagation of a bore-like translation wave into a shelving channel may be a marked increase in amplitude of the oncoming, as also of the reflected wave.

On the other hand, the reflection of a translation can be studied in the limiting case of a vertical wall blocking off a constant-depth canal by applying equation (25); the first term on the right-hand side drops out, and $a$ and $\delta a$ are both first-order small quantities. 
We find :

$$
\delta a=a\left(1+\frac{a}{2 h}\right)
$$

so that the total rise in level after the return of the reflected wave is given by:

$$
a+\delta a=2 a+\frac{a^{2}}{2 h}
$$

\section{PART 3. - EXPERIMENTAL STUDY}

Experiments have been conducted in the flume shown in fig. 4 (French text). The modus operandi was as follows : :

The water level inside the flume was set at a known level above (or below) the water level in the constant-level basin by bucketing (or siphoning). The lift gate at one end of the canal was then opened rapidly and the ensuing motion recorded at points $A, B, C, D, E$, by electronic wave recorders of the type invented by $M$. BouDAN and described in his article "Appareils pour la mesure des niveaux rapidement variables' sur modèle réduit 》. La Honille Blanche, $\mathrm{N}^{\circ} 4$, August-September, 1953.

A first series of tests was carried out with the flume sides and bottom smooth (coefficient de Chézy $=60$ and 70 in metric units for a hydraulic radius $=0.02 \mathrm{~m}$ and $0.10 \mathrm{~m}$ respectively), and a second series of tests with additional roughness. This is equivalent, as far as the ordinary translation wave theory goes, to a flattening of the canal bottom without a change in roughnes's; the transmission and reflection of waves takes place just as though, keeping the same smoothness, the slope were about 10 times flatler than in the first case, i.e. as if it were about $0.95 \%$ instead of $9.5 \%$.

It proved difficull to follow the change in height of the initial wave. However, the maximum rise or fall in water level for a $20 \mathrm{~mm}$ wave proceeding in water of about $300 \mathrm{~mm}$ (for the positive waves) or $340 \mathrm{~mm}$ (for the negative waves) initial depth at section A did not exceed $2 a$, i.e., $40 \mathrm{~mm}$, by more than $10 \%$ over $85 \%$ (positive) and $60 \%$ (negative) of the travel based on the initial length of the water surface over the sloping bottom, i.e. $85 \%$ of $3.15 \mathrm{~m}$ and $60 \%$ of $3.60 \mathrm{~m}$ respectively. These figures apply to the smooth flume; with artificial rugosity, the maximum difference in level was roughly $10 \%$ smaller, so that a $40 \mathrm{~mm}$ level difference was actually not attained over the distances stated. The maximum difference in level could not be directly measured at the top end of the flume, where breaking of the wave front occurred (even locally with negative waves, during the reflection), and the electrical probe could not be maintained continuously under water. However, for positive waves and the steep slope, this could be estimated at about $55 \mathrm{~mm}$ above the initial level (i.e. from $35 \%$ to $40 \%$ increase over $2 a=40 \mathrm{~mm}$ ) and at about $55 \mathrm{~mm}$ under the initial level for negative waves: for the experiments with artificial roughness, figures of about $25 \%$ to $30 \%$ increase could be expected, so that once again a ten-fold increase in slope without change in roughness' would be equivalent to about a $10 \%$ reduction in the excess amplitude percentages.

The recordings did not permit of an accurate study of the change in slope of the wave front.

These results show that reflection from a smooth, sloping bottom may be more unfavourable than that occurring from a vertical wall (eqn. 28) in the case of steen slopes, but shows that the trouble is localized near the original shoreline. For flatter canals (1\% slope or less), a doubling of the wave amplitude will be exceeded markedly, if at all, only in quite shallow depths.

\section{CONCLUSION}

The principal conclusion is that, as far as barges are concerned, the main difficulties arising from the propagation of translation waves in shallow depth water are likely to be connected with the inevitable steepening up and breaking (of positive waves); see Part 1 of the article.

The rise and fall in water level will rarely be markedly different in practice from that occurring with reflection from a vertical wall, as discussed in Part 2; this assertion is hased on the experimental results given in Part 3.

The article by J. J. Stoker on the "Formation of Breakers and Bores ", in Communications on Applied Mathematics, vol. 1, $\mathrm{N}^{\circ} 1,1948$, may be referred to by the reader wishing to interrelate the subject treated here with other phases of Fluid Mechanics. 